\title{
Conceptual Framework of the Model of Forming Interethnic Tolerance in the Multicultural Environment of the University
}

\author{
Aida Ussenova1*, Irina Malakhova², Mariya Shmidt³, Saltanat Tuliepova4, Aiym Tynyskhanova
}

${ }^{1}$ Faculty of Physical culture and Art, Head Department of Creative education, Zhetysu State University named after I. Zhansugurov, Zheltoksan ave., Taldykorgan, Kazakhstan, e-mail: wcit.info@gmail.com, aiym_t.t@mail.ru

${ }^{2}$ Head Department of Psychology and Pedagogy, Belarusian State University Culture and Art, Robkorovskaya ave., Minsk, Belarus, e-mail: creativmi@yndex.by

${ }^{3}$ Faculty of Pedagogy and Psychology, Department of Teaching Methods and education, Zhetysu State University named after I. Zhansugurov, Taldykorgan, Kazakhstan, e-mail: smidtm@mail.ru

${ }^{4}$ Faculty of Pedagogy and Psychology, Department of Pedagogy and Psychology, Zhetysu State University named after I. Zhansugurov, Taldykorgan, Kazakhstan, e-mail: tuliepova.saltanat.80@mail.ru

\begin{abstract}
The aim of this research is to study the state, dynamics and factors affecting the interethnic relations of young people in the field of education. This article discusses the conceptual foundations of the structural and content model of forming interethnic tolerance of young people in a multicultural environment of the university. Particular attention is paid to the study of new educational strategies and approaches that can create the desired socio-cultural and theoretical tolerance of representatives of other cultures, ethnic groups and religions. The research was a mixed method research and it made use of both quantitative and qualitative data. Secondary data for the article was derived from the scientific publications of other researchers and primary data was collected with the help of focus groups and indepth interviews. The 1000 participants of the research were carefully selected to represent nationals of other countries, culture and religion, to reduce the bias that sociological studies exhibit. The hierachy technique was used to analyze qualitative data. The authors present the results and analysis of sociological research for the analysis of interethnic tolerance of young people. It focuses on the psychological and pedagogical content of the phenomenon of interethnic tolerance, that can be taught to students in school. The authors offer evidence-based conclusions and recommendations on the organization of the process of forming interethnic tolerance of young people in a multicultural environment of the university.
\end{abstract}

Keywords: interethnic tolerance, multicultural environment, pedagogical concept, structural and content model.

\section{Introduction}

In the period where the Republic of Kazakhstan got its independence, some of the notable issues that the citizens had to deal with were interethnic relations and interethnic harmony. Kazakhstan supports the co-existence of people from different nationalities, races, religious views, and beliefs. This level of tolerance over the years has become a special Kazakh subculture, which distinguishes the model of the true Kazakh mentality.

The First President of the Republic of Kazakhstan, Nazarbayev (1996), in the book 'On the threshold of the XXI century', explained, "The transformation of the national idea into the idea of national exclusivity is fatal for the ethnos... Many states where they failed to recognise the positive and negative beginnings of the rise of ethnicity-consciousness have become the arena of protracted wars'. Yugoslavia, Algeria, modern Afghanistan, many African States are examples of states that failed to recognise the positive and negative beginnings of the rise in ethnicity consciousness.

In October 2008, the principles of the National Policy in Kazakhstan were developed and tested in practice. In Kazakhstan's model of interethnic harmony, the following aspects were identified: the consolidating role of the Kazakh ethnic group; tolerance; ethnic diversity, religious diversity, cultural and linguistic diversity; conditions for the development of culture and languages of ethnic groups of Kazakhstan.

\footnotetext{
“Corresponding author:wcit.info@gmail.com
} 
The goal of the present Kazakhstan generation is to become one of the most competitive civilised countries in the world. Active innovative processes in the socio-economic and political life of modern society have put the education system in need for a revision of both the traditional and new approaches used in the practical training of young professionals in all spheres of public life (Konst and KairistoMertanen 2019; Ahi and Alisinanoglu, 2018; Vasiliene-Vasiliauskiene et al., 2020). A graduate of the university should have a culture of interethnic communication and interaction, have a tolerant mindset towards representatives of different ethnic groups living in a single territory, take into account the religious, regional and national specifics of the individual in the process of future professional activity and have intercultural competence in solving professional problems (Zhumabayeva, et al., 2019; Bagila et al., 2019; Agranovich et al., 2019; Usmani and Khatoon 2018; Elçi and Uzunboylu, 2020).

Interpersonal interaction in the modern world is one of the topical problems that need to be addressed. This is because most people lack the ability to interact effectively with other people (Kayedkhordeh, Mousavi and Abdi, 2018), to anticipate emotions, intentions, motivation of the interlocutor, the ability to manage their emotions and emotions of other people and to build emotional connections (Masat et al., 2018). It is necessary to develop emotional intelligence including empathy, acceptance of a person of another faith, nationality and religious views and beliefs, which makes the study unique (Ozkisi and Topaloglu 2018; Sorakin-Balli, Basari and Guldal-Kan, 2020). Uzunboylu and Altay (2019) reviewed of studies on multicultural education around the world. They found that more than half of the empirical studies employ a qualitative research about multicultural education design.

Culture is one of people's means of understanding and tolerating each other (Kececi and Kececi, 2016). Multicultural education, which is one of the most important features of the $21^{\text {st }}$ century, is expanding its applications day by day (Emrali, 2017). It increases multiculturalism especially in communication established with technological tools (Pinpathomrat, 2017). In this process, it is very important for university students to learn new knowledge as a multicultural education (Al-Bataineh et al., 2019). In this process, students' tolerance and acceptance of each other is one of the most important indicators (Simion, 2016).

In this work, the formation of interethnic tolerance of young people in a multicultural environment of the university is grounded on the structural and content model, which is actively used by modern researchers in various fields of science. It allows building mechanisms of educational impact on the formation of interethnic tolerance of students.

The main objective of the study is to find and develop effective methods for the formation of interethnic tolerance. The introduction of the methods into the content of education focused on the study of the theory, methodology and practice of interethnic tolerance in the pedagogical and socio-cultural spheres.

The aim of the research is to study the state, dynamics and factors affecting the interethnic relations of young people in the field of education.

Tasks of research:

1. To study the problem of interethnic tolerance and dynamics of changes in relations between different ethnic groups.

2. To determine the structure of identification of different ethnic groups.

3. To identify the degree of integration of ethnic groups.

4. To determine the level of interethnic tolerance, preservation of ethnic diversity and assessment of the prospects of interethnic relations.

5. To study the effectiveness of the implementation of the state policy in the field of interethnic unity and harmony.

\section{Materials and methods}

The methodological basis of the research is the conceptual provision of modern science about humans and the factors influencing their self-development (Agha and ELDaou, 2018). It centres on the dialogical nature of culture and education, the revival of the humanistic paradigm of education, the development of cultural diversity and traditional culture in the formation of national and cultural identity, cultural-oriented education and the integration of the construction of the educational process (Agha and ELDaou, 2018).

Focusing on the psychological and pedagogical content of the phenomenon of interethnic tolerance, without understanding of which it is difficult to expect the creation of adequate and effective pedagogical strategies, and the analysis of sociological studies, similar to that of Gokal (2019) to diagnose the general level of interethnic tolerance of young people. The article uses the results of sociological research on interethnic relations of young people conducted in 2018 by the public Fund "Center for political and social 
research" of Almaty region. The sociological survey uses focus group studies, expert evaluation, methods of statistical processing and qualitative analysis of the results. This research just like most educational research, uses a mixed method (Winch, 2020). The method of hierarchy analysis is used to predict social research.

\section{Participants}

The reason for the selection of the sociological research results obtained from "Centre for political and social research" of Almaty region was that it contained the issues of interethnic interaction and harmony, which plays an important role in the formation of interethnic tolerance of young people in a multicultural environment.

The integral assessment of the state of interethnic relations and interethnic tolerance in the conditions of the multicultural environment of the university is an indicator. In total, there were 1000 respondents to the research. The respondents, aged between 18 to 22 years and representing different social backgrounds and specialties were interviewed. The nature of the ethnic affiliation of young people is shown in the figure 1. Among the participants, 636 people are Kazakhs, 161 people are Russian, 80 Uighurs, 49 Tatars, 28 Turks, 25 Koreans, 14 Germans, 4 Ukrainians, and 3 representatives of the Azerbaijan diaspora.

\section{Data Collection}

The article uses scientific and special methods, study and generalized analysis of scientific sources and documents, comparative analysis of scientific and methodological literature on the problem of research in the field of sociology, psychology, pedagogy and ethno-pedagogics, modelling, poll, questioning and interview, and presentation of long-term experience of research activities in the field of pedagogy and socio-cultural activities. The major source of data for this research is secondary data, obtained from the public Fund "Center for political and social research" of Almaty region.

Data was collected through focus group surveys and in-depth interviews with the participants of this research. The hierarchy technique for analysis was used to analyse the qualitative data of this research. The special methodology is composed of the following works reflecting the modern humanistic paradigm in education: a system-structural approach (Balyasnaya, 1995; Bespalko and Tatur, 1989), the project approach (Mazur, 2014) for studying the general principles and requirements of the education system, the axiological approach (Damy and Plascencia, 2020) for analysing the processes and phenomena of vocational education in the socio-cultural sphere, and the integrative approach (Anastasiadou, 2019; Gershunsky, 2002; Pidkasisty, Fridman and Garunov, 1999), which ensures the integrity and consistency of the pedagogical process.

\section{Results}

From the statements of some of the respondents in the course of the study, it was discovered that there is a deterioration of the relationship between different ethnic groups. These are isolated cases of violations of rights on the basis of language, and these problems are common among young people.

\section{Figure 1.}

Focus group survey results

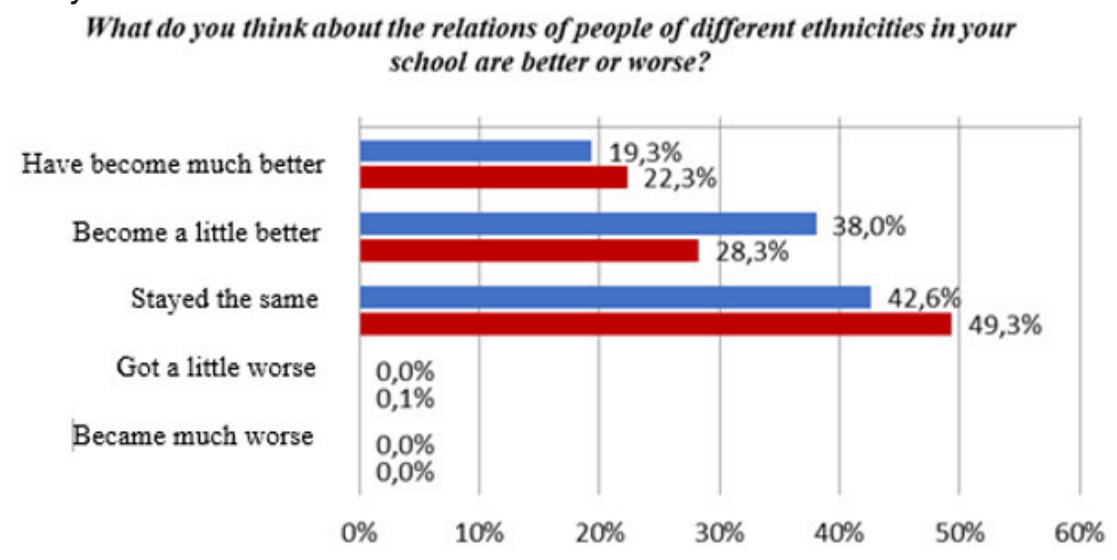

www.ijcrsee.com 
Answers to the question "How do you feel about representatives of other ethnic groups, their religion and customs?" This question was used to assess the degree of interethnic tolerance of young people in the educational environment to representatives of other ethnic groups. In general, it can be stated that the majority of respondents have a stable positive perception of the customs and religion of other ethnic groups, and are open to ethnic communication. This perception is due to the assimilation processes, common historical destinies of peoples, the so-called phenomenon of the "United Soviet people", and the joint holding of various events.

\section{Figure 2.}

Focus group survey results

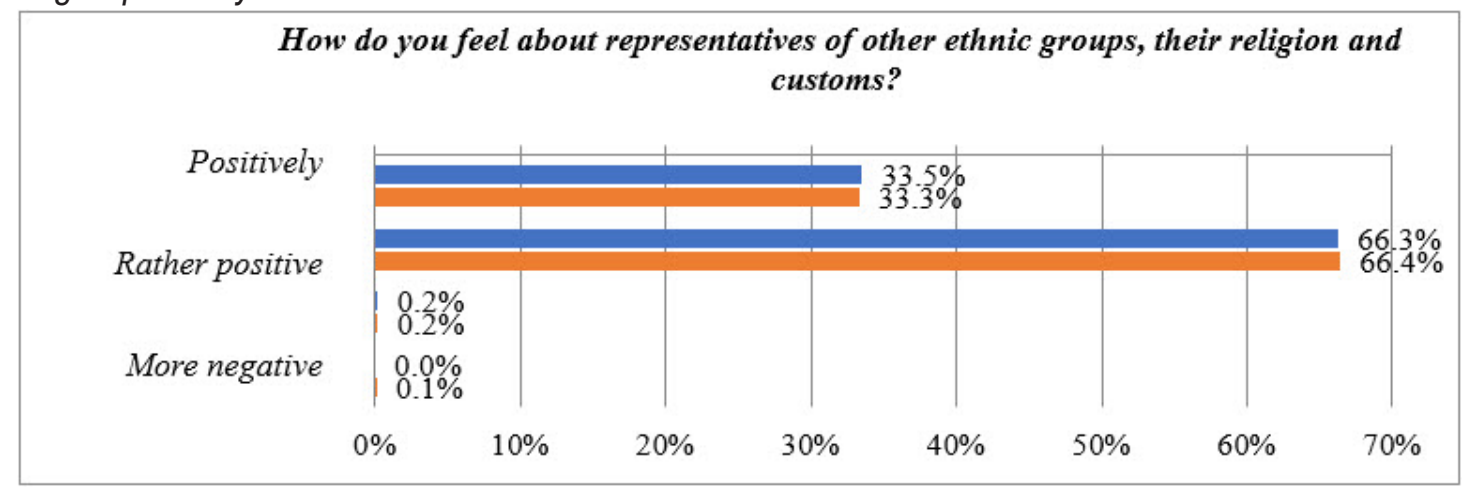

To the question, "Are there representatives of another ethnic group in your family?" To this question, $24.7 \%$ of the respondents answered "Yes", and $75.3 \%$ respondents answered "no".

To the question, "How do you feel about the fact that someone from close relatives can become related to representatives of another ethnic group (nationality)?" $49.9 \%$ of young people surveyed said that they are not against interethnic marriages, if only they were decent people. In general, there is a tendency to tolerate interethnic marriages in the majority of respondents, regardless of ethnicity. Less frequently, respondents pointed to the unacceptability of inter-ethnic marriages. Most often representatives of the Kazakh ethnic group -repatriates "oralmans", citing the desire to preserve ethnic identity, pointed this out.

Table 1.

Focus group survey results

Take this negatively, maybe will let

$0,0 \%$

It depends on which ethnic group she/he is with

$22,7 \%$

How do you feel about the fact that someone from close

I do not approve; I think it is better to avoid it

$2,1 \%$

relatives can become related to

representatives of another

It's all the same to me

$22,9 \%$

ethnic group (nationality)?

Not judging, if these representatives are people of good character

$49,9 \%$

I welcome and promote; ethnicity is not the main thing

$2,4 \%$

Total

$100,0 \%$

According to the participants of the study, any conflict situations between representatives of different nationalities can only occur in the form of scuffles and fights involving no more than a few people, with the causes of what is happening, in most cases, domestic.

In everyday life, places of localization of interethnic tension are areas related to formal organizations, and the area of short-term, impersonal contacts (public transport, shops, cafes, cinemas, etc.). The intensity of such phenomena is low, however, such phenomena are a serious danger, because under certain conditions (a factor or an event that stimulates ethnic strife), they have a very high potential for spread in the form of "social infection". The most common behaviors of the respondents as a response to the inability to solve the problem, is a peaceful settlement of the conflict. Less often in the manifestation 
of aggression, respondents are ready to demand action from the authorities.

In determining the civil and ethnic identity, it is important to understand how the beliefs and attitudes of young people in social relations contribute to the formation of civic identity.

Young people support the policy pursued by the state in the field of inter-ethnic relations, in most cases. According to respondents, interethnic harmony will contribute to the preservation of the country's independence and economic prosperity. The results of the study show that civil identification is primary for the majority of representatives of all ethnic groups. Most often, they define their community through a small homeland, the whole country, as well as through categories such as family, friends, etc.

In a sociological survey, respondents were asked, "How do you assess the relations between different ethnic groups in the country?" The interethnic situation in the region was assessed as calm by $47.5 \%$ of respondents. More than a third $(35.6 \%)$ of respondents consider the relations between ethnic groups in the country to be good. The total number of low assessments of the situation, which are "tense" and "conflict" are respectively $9.7 \%$ and $2.5 \%$, which is less than $12 \%$ of respondents.

Figure 3.

Focus group survey results

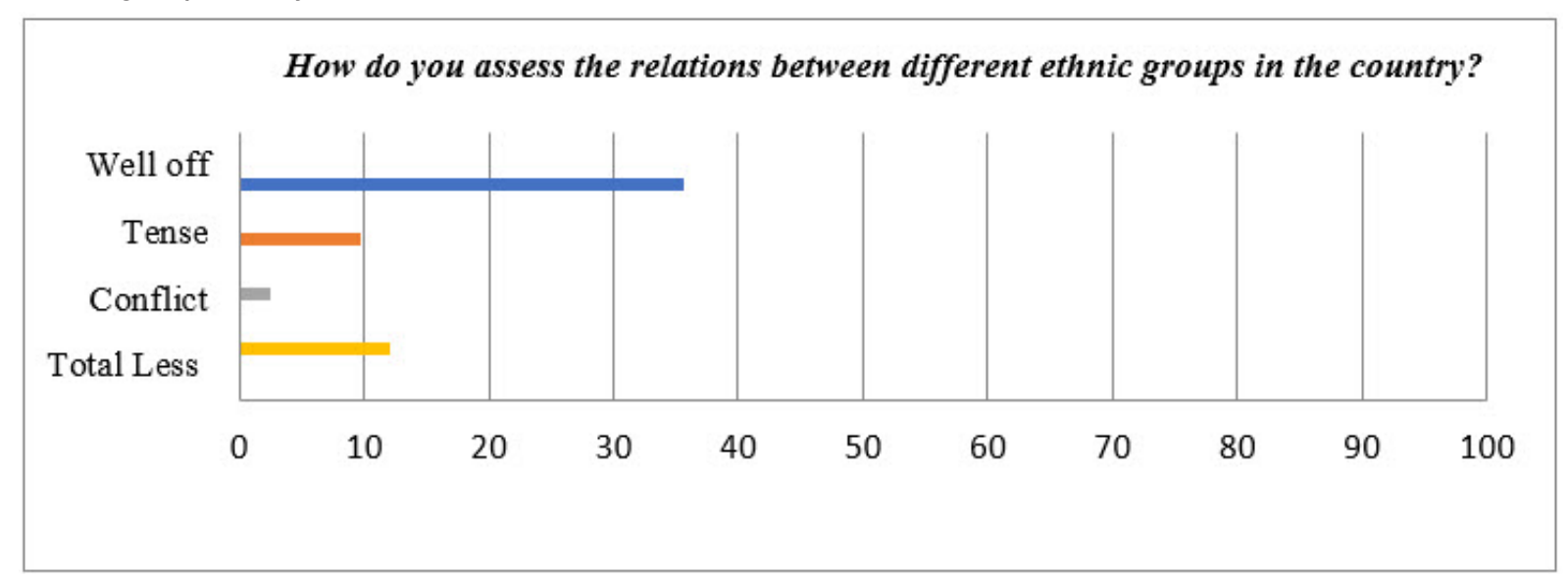

Analyzing the answers of respondents to the question "What, in your opinion, is the main condition for determining your belongingness to a single nation?" Three most important characteristics for respondents in determining belongingness to a single nation are birth in the territory of their country $-91.3 \%$, issued citizenship in the certificate like passport $-89 \%$, and knowledge of the native language $-85.5 \%$.

\section{Figure 4.}

Focus group survey results

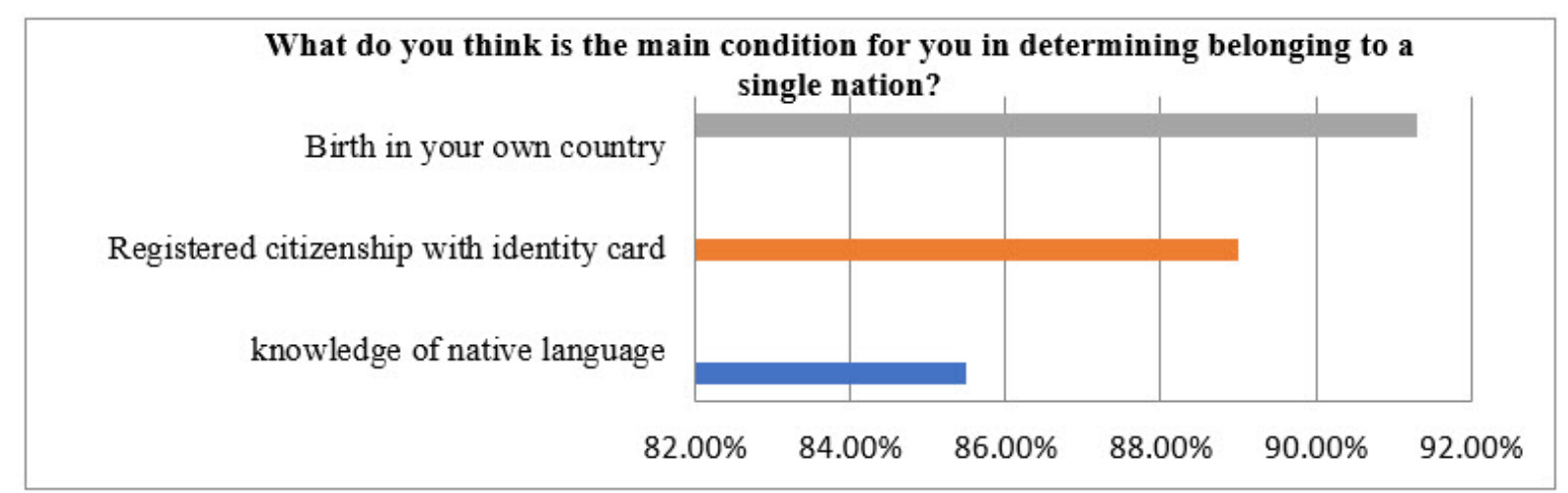

To the question, "Can you say that you consider yourself a citizen of your country, i.e. a representative of one people?" Hundred percent (100\%) of respondents consider themselves citizens of their country, i.e., representatives of a single people. 
Figure 5.

Focus group survey results

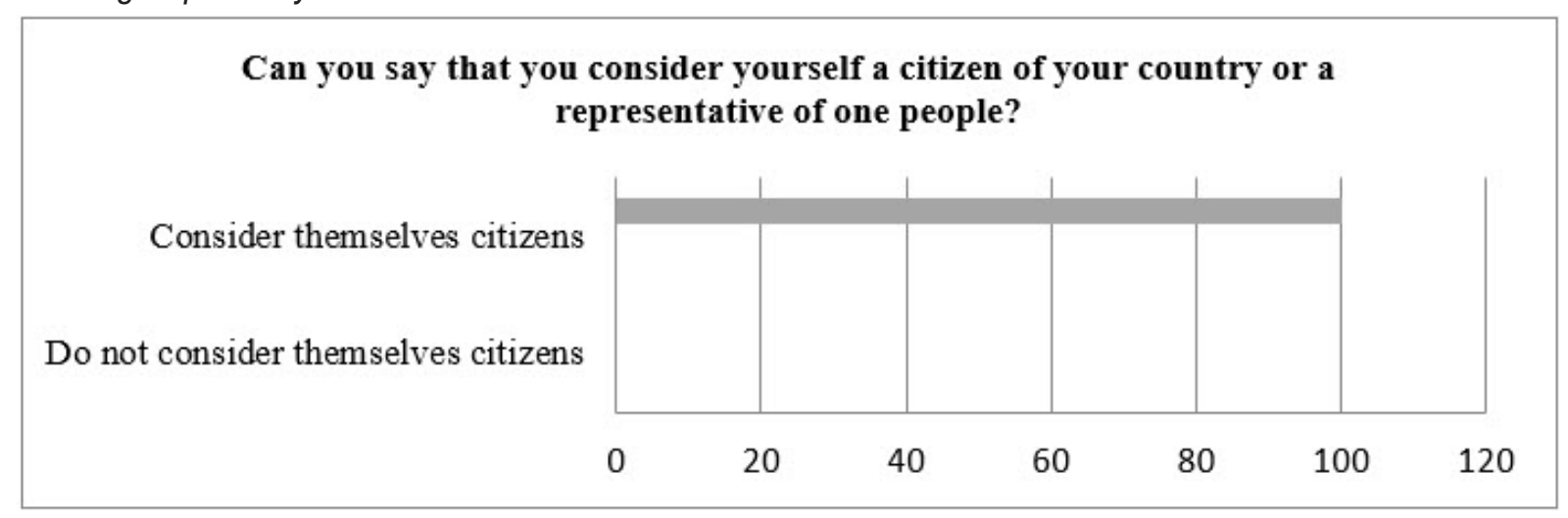

Thus, regardless of what ethnic group, religion, place of birth, or place of residence, people consider themselves as citizens of their country. In addition, the overwhelming number of respondents identified themselves as representatives of a single people of their country, which speaks of community, tolerance and unity.

The study showed that to the question "Do you observe traditional holidays, rituals, customs of your ethnic group?" almost all respondents respond positively. The answers to the first question on the questionnaire for the student audience are diverse. As evident in the results, the column "Yes, I always observe" is at a high level - 55.6\%; at the average level - 57.4\%; at a low level $-1.8 \%$. Almost all respondents answered positively on this question. It should be noted that the observance of traditional holidays, rituals, and customs is characteristic of all, regardless of what ethnic group they are.

Figure 6.

Focus group survey results

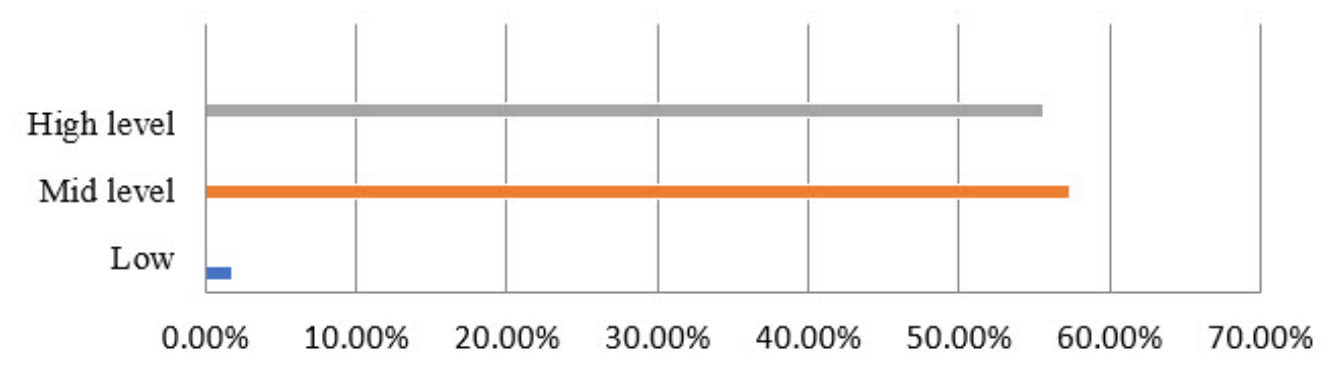

Thus, the analysis of the results of sociological research gives grounds to believe that in the multicultural environment of the university, there is a calm ethno-social situation. However, there are signs of hidden ethnic tension in the student community, which cannot go unnoticed. In this regard, there is an urgent need to determine the model of formation of inter-ethnic tolerance of young people, which will be most effective for modern Kazakhstan and can be used in socio-cultural practice.

The scientific basis of the study was the socio-cultural approach which is the idea of 'cultural mediation' associated with the understanding of the symbolic context of interpersonal interactions and ethno-cultural-oriented approach (Stefanenko, 2008; Metin and Aral, 2020), as tools of culture, acting as a means of mastering a person's own psyche, consciousness and personality.

The relevant research of Öksüz and Öztürk, (2017) is a multicultural approach based on multicultural education as a necessary condition for tolerant coexistence of various ethnic and cultural groups. The study was conducted in the fields of psychological and pedagogical sciences: ethno-psychological approach, based on the study of similarities and differences of psychological variables in different cultures and ethnic communities (Miyamoto 2018; Triandis, 1994); ethno-pedagogic approach, revealing the importance of national educational experience in the formation of personality; and environmental approach considered as a set of influences and conditions that ensure the implementation of the educational process. The priority for the study was the study of Rubinstein (2003) an ontological approach based on ethics included in the ontology or ontologically oriented content of education. 
Among the practical prerequisites of the study are a number of legal documents that mark the mission of interethnic tolerance in the development of multicultural diversity of the country, and are the subject of intercultural interaction and social harmony, materials of the domestic and foreign periodicals, scientific sources and applied research of the authors. In general, the opinion of the majority of respondents, regardless of nationality and region of residence, on various aspects of inter-ethnic tolerance is characterized by a consensus, which indicates a high degree of inter-ethnic harmony in educational institutions.

\section{Discussion and Conclusion}

The main purpose of education, arising from the modern understanding of the mechanisms of development of human civilization, is to ensure the advanced development of creative qualities and abilities of man, familiarizing him with the values of the world and national culture, education of spirituality, morality, patriotism, tolerance, and humanism in all subjects of the educational process (Cakmak and Uzunboylu, 2018). In a research, Tenbele (2019) concluded that higher educational institutes have the ability to change the perspective of students by modifying their pedagogical method.

The above-mentioned determines the principal role of the pedagogical phenomenon of interethnic tolerance in the education system, which acts as one of the main state and public institutions responsible for the organization of a common spiritual space, preparation of the individual for life in a multicultural society and full self-realization of each individual.

1. As a result of empirical studies, internal and external factors influencing the formation of interethnic tolerance were identified. The study of the problem revealed the components of the formation of interethnic tolerance: ethno-cultural, cognitive-evaluative, emotional-reflective, operational (see diagram 1).

2. Studying various aspects of the problem of forming interethnic tolerance of young people, we inevitably come to consider the possible application or implementation of this phenomenon. The direct object of research in our work is the multicultural space of ethno-cultural associations. Considering the Concept of development of the Assembly of people of Kazakhstan (until 2025) from December 28, 2015, we have identified the principles and foundations of education, corresponding to the system of conditions for the formation of inter-ethnic tolerance of young people, which is based on the theoretical study of the problem of research. This concept is a systematized basic guideline aimed at the formation of national unity, ensuring social harmony and stability, increasing the dynamics in the field of inter-ethnic relations and improving mechanisms through a multicultural educational environment. The problem of inter-ethnic tolerance is relevant for these institutions, as they unite people of different nationalities and cultures. We consider this existing system of education as a model of formation of interethnic tolerance of youth.

3. Creation of the author's model of forming interethnic tolerance of youth in the conditions of multicultural educational environment of the university was carried out simultaneously in two directions: a) definition of its structure and content; b) development of ways of its implementation.

4. The designed structural and substantial model of formation of interethnic tolerance of youth is considered as a subsystem of open type, built in the context of the system of professional training of specialists at the university. This model is a set of interrelated blocks: target, operational, effective.

The target block of the model defines the purpose, objectives and conceptual approaches to the formation of interethnic tolerance of young people in a multicultural environment of the university. The operational block of the model contains the unity of interrelated components, organizational and content component that determines the software implementation of the goal; activity-technological component of the model determines the organization of the process of forming interethnic tolerance of youth; criteriadiagnostic component of the model includes criteria, indicators and levels of formation of interethnic tolerance of young people. The effective block of the model determines the effectiveness of the results of the formation of interethnic tolerance of students in a multicultural environment 


\section{Diagram 1.}

Components of formation of interethnic tolerance

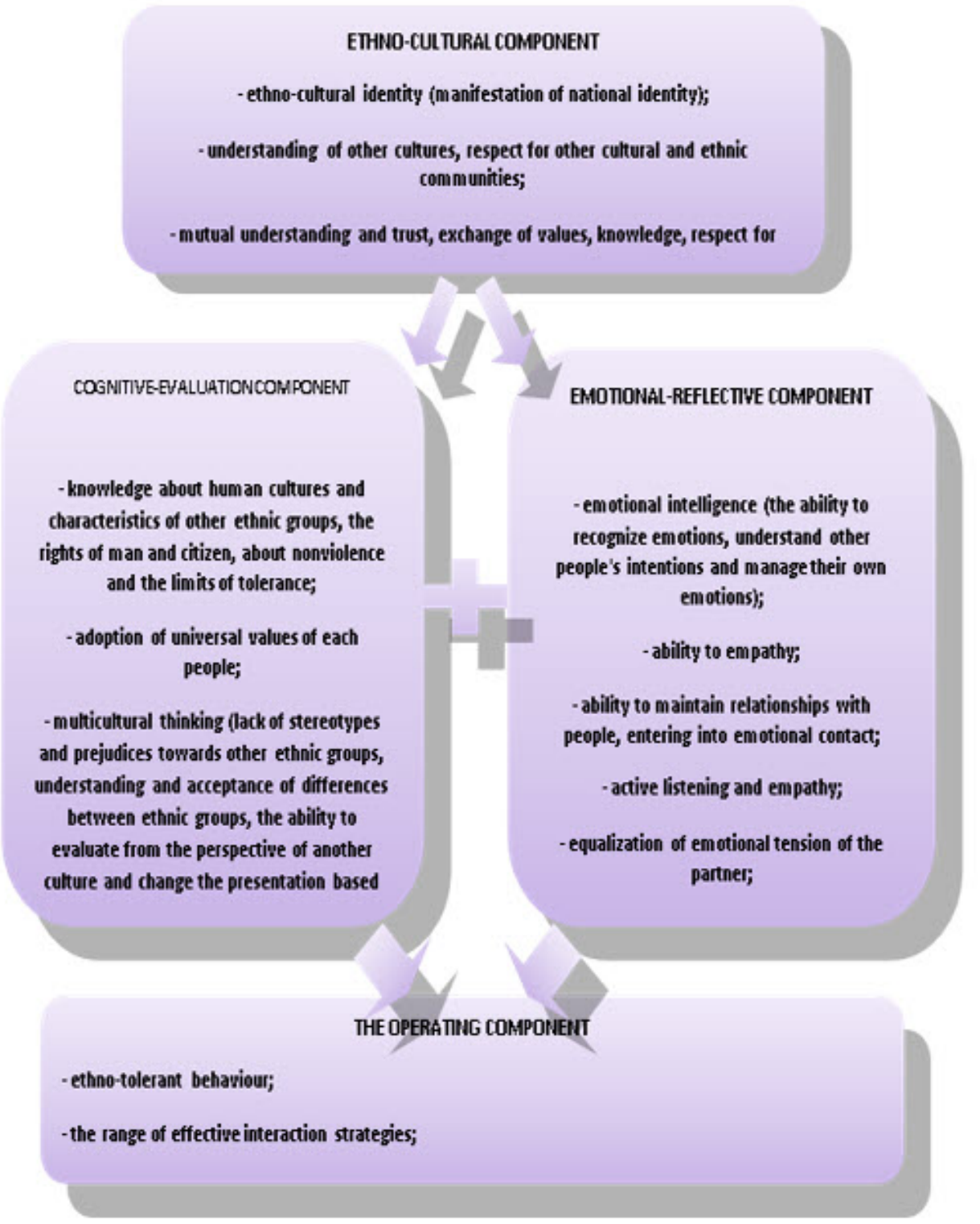




\section{Scheme 2.}

Model of forming interethnic tolerance of youth

\begin{tabular}{|c|c|c|c|c|c|c|c|c|}
\hline \multicolumn{9}{|c|}{ TARGET BLOCK } \\
\hline \multirow{11}{*}{ 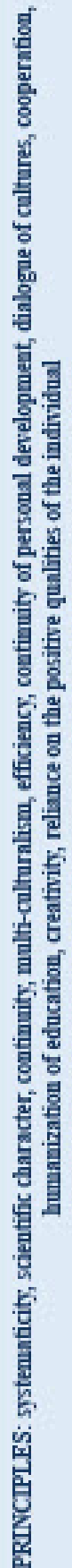 } & AlM & \multicolumn{6}{|c|}{ TASKS } & \\
\hline & $\begin{array}{l}\text { Formation of } \\
\text { interethnic tolerance } \\
\text { of youmg people in a } \\
\text { multicultural } \\
\text { enviromment of the } \\
\text { university to } \\
\text { motivate young } \\
\text { people to participate } \\
\text { in the process of } \\
\text { preservation and } \\
\text { development of } \\
\text { national cultural } \\
\text { heritage and } \\
\text { intercultural } \\
\text { cooperation of } \\
\text { ethric groups }\end{array}$ & \multicolumn{2}{|c|}{$\begin{array}{l}\text { Formation of culture } \\
\text { of irterethnic } \\
\text { communication, } \\
\text { patriotism ard love } \\
\text { for the Motherland. } \\
\text { national } \\
\text { consciousuess; } \\
\text { development of } \\
\text { munual understanding. } \\
\text { trust and respect for } \\
\text { culturel traditions of } \\
\text { other ethmic groups. }\end{array}$} & $\begin{array}{l}\text { Formation of } \\
\text { bmowiledge about } \\
\text { human culnure and the } \\
\text { characteristics of other } \\
\text { ethric groups, buman } \\
\text { and civil nights, non- } \\
\text { violence and the } \\
\text { boundaries of } \\
\text { tolerance; } \\
\text { development of } \\
\text { multicultural thinking } \\
\text { the ability to assess } \\
\text { from the perspective } \\
\text { of mother culture. }\end{array}$ & $\begin{array}{l}\text { Development of } \\
\text { emotional } \\
\text { intelligence, ability to } \\
\text { empathy; formation of } \\
\text { the abulity to build } \\
\text { constructive } \\
\text { relationsipips with } \\
\text { other ethnic groups } \\
\text { without coercion. } \\
\text { problems amd } \\
\text { contradictions }\end{array}$ & \multicolumn{2}{|c|}{$\begin{array}{l}\text { Formation of ethro- } \\
\text { tolerant behavior, skills } \\
\text { and abilities of } \\
\text { intercultural } \\
\text { communication. } \\
\text { selection of effective } \\
\text { strategies of interaction } \\
\text { to overcome problematic } \\
\text { siruations, prevention } \\
\text { and resolution of } \\
\text { conflicts in the } \\
\text { interaction of ethric } \\
\text { groups. }\end{array}$} & 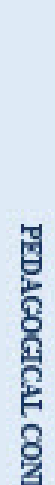 \\
\hline & \multicolumn{7}{|c|}{$\begin{array}{l}\text { APPROACHES: multicultural, ethno-cultural-oriented, ontological, axiological, system-structural, integrated, ethno- } \\
\text { psychological, environmental, efhno-pedagogic }\end{array}$} & 悬 \\
\hline & \multicolumn{7}{|c|}{ OPERATIONALBLOCK } & 骨 \\
\hline & \multicolumn{7}{|c|}{ ORGANIZATIONAL-SUBSTANTIAL COMPONENT } & \\
\hline & \multicolumn{2}{|c|}{$\begin{array}{l}\text { Development of software and } \\
\text { methodological materials for } \\
\text { teaching students in higher } \\
\text { education }\end{array}$} & \multicolumn{2}{|c|}{$\begin{array}{l}\text { The elective course "Pedagogy of } \\
\text { forming interethnic tolerance" for } \\
\text { students of the university }\end{array}$} & \multicolumn{3}{|c|}{$\begin{array}{l}\text { Creation of ethno-cultural certer "Tolerant" } \\
\text { as a social instifution for intercultural } \\
\text { cooperation of ethnic groups at the } \\
\text { university }\end{array}$} & 窟 \\
\hline & \multicolumn{7}{|c|}{ ACTIVITY-TECHNOLOGY COMPONENT } & e \\
\hline & \multicolumn{2}{|c|}{$\begin{array}{l}\text { Technologies of forming } \\
\text { interethnic tolerance: ethno- } \\
\text { cultural, cultural, project, } \\
\text { infonmation and echucational, } \\
\text { infonnation and } \\
\text { communicative }\end{array}$} & \multicolumn{2}{|c|}{$\begin{array}{l}\text { Forms of training organization: } \\
\text { Group - lecture, seminar, conference, } \\
\text { discussion, debate, master class, } \\
\text { pedagogical workshop, training, modeling } \\
\text { of situations, round table. } \\
\text { Individusl- self-analysis, self-2ssessment, } \\
\text { gelf-diagnosis, self-education, training. } \\
\text { eramination, supervision, dissemination of } \\
\text { experience, etc. }\end{array}$} & \multicolumn{3}{|c|}{$\begin{array}{l}\text { Teaching AIDS: texching AIDS, books, } \\
\text { computer, nultimedia equipment websites, } \\
\text { portals, movies, video lessons, etc. }\end{array}$} & 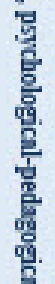 \\
\hline & \multicolumn{7}{|c|}{ CRITERIAL-DIAGNOSTIC COMIPONENT } & \\
\hline & $\begin{array}{l}\text { emotional-reflegive } \\
\text { operating- } \\
\text { communicative }\end{array}$ & & \multicolumn{4}{|c|}{ 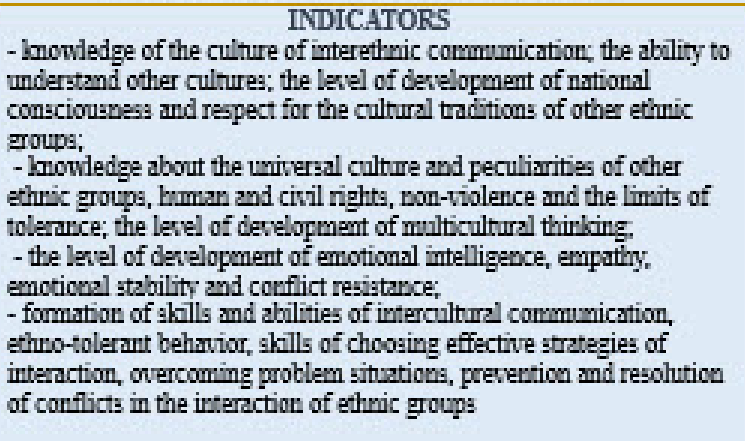 } & $\begin{array}{l}\text { LEVELS } \\
\text { high } \\
\text { zwerage } \\
\text { low }\end{array}$ & 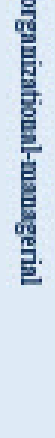 \\
\hline & \multicolumn{7}{|c|}{$\mathrm{OCK}$} & \\
\hline
\end{tabular}

The implementation of the process of forming interethnic tolerance of young people will be accompanied by a high-quality level of certain conditions and principles. The conditions may include organizational-pedagogical, psychological-pedagogical, organizational-managerial, and the principles may include consistency, scientific, continuity, multiculturalism, effectiveness, continuity of personality development, dialogue of cultures, cooperation, humanization of education, creativity, reliance on positive qualities of the individual, allowing for the stimulation of this process in a multicultural environment of the university. The principles and conditions of forming interethnic tolerance of youth according to the authors of this research are the basis of pedagogical model of formation of interethnic tolerance of youth. Thus, the model of formation of interethnic tolerance is a systematic inclusion of different components of research and generally requires a creative approach to the understanding, production and implementation of the goal (see figure 2). 


\section{Implications and Recommendations}

As a result of the study, we found that the feature of the author's model of forming interethnic tolerance of young people in a multicultural environment is its integrity, ensuring the unity of content (purpose, content of the process, result) and structural components (principles, conditions, pedagogical assistance, criteria, levels and indicators of formation of interethnic tolerance). This process is a unity of internal and external factors that determine the formation of interethnic tolerance: ethno-cultural, cognitiveevaluative, emotional-behavioral, and operational. Formation of interethnic tolerance in the multicultural environment of the university is aimed at theoretical, methodological and practical readiness of young people to understand the values and cultures of different people and the integration of the ideas of ethnopedagogy and pedagogy in the development of young people's abilities and skills tolerant inter-ethnic interaction, ethnic and cultural responsibility.

The model of forming interethnic tolerance of youth is a set of interrelated blocks: target, operational, effective and unity of components; organizational and content; activity-technological; criteria-diagnostic. For approbation of "organizational and pedagogical", "psychological and pedagogical" and "organizational and administrative" conditions of forming interethnic tolerance of youth, experimental works will be carried out, allowing to present results of the studied processes and phenomena in dynamics, to define tendencies and regularities of real interaction of integrative qualities of the investigated phenomenon.

The results of the study was confirmed by the effectiveness of the formation of interethnic tolerance of young people in the integrated implementation of pedagogical techniques in a multicultural educational environment which motivates young people to participate in the process of preservation and development of national, cultural heritage and intercultural cooperation of ethnic groups;

The use of the potential of ethno-cultural associations will contribute mostly to the formation of inter-ethnic tolerance of young people under the following conditions:

1) taking into account the set of principles, forms and methods of socio-cultural activities in working with young people to develop inter-ethnic tolerance;

2) monitoring according to certain criteria, showing the level of formation of interethnic tolerance of students in a multicultural environment;

3 ) introduction of the author's model and pedagogical program for the formation of interethnic tolerance of students in the pedagogical process;

4) expansion of intercultural relations of ethno-cultural associations with other subjects of social and cultural activities, contributing to the formation of interethnic tolerance of students.

One notable limitation of this study is that it cannot be generalized for other countries due to the geographical positioning of the research. This is because the research was conducted in Kazakhstan and even though people from other nationalities participated in the research, there may exist a different mindset or mentality if this research is replicated in a different country. The researchers therefore recommend that future researchers consider replicating this research in different countries to validate further the results of this research.

\section{Acknowledgement}

Article is executed within a framework of grant from the Ministry of Education and Science of the Republic of Kazakhstan, according to the budgetary program 217 "Development of science", the subprogram 102 "Grant funding for research", the project AP05130884 "Formation of interethnic tolerance of the student's youth in the conditions of the multicultural educational environment". State number registration is 0118PK00020.

\section{Conflict of interests}

The authors declare no conflict of interest.

\section{References}

Agha, Z., \& ELDaou, B. (2018). The role of the special education centers in developing students' holistic wellbeing. Journal of Education and Special Education Technology, 4(1), 1-13. https://doi.org/10.18844/jeset.v4i1.4056

Agha, Z., \& ELDaou, B. (2018). The role of the special education centers in developing students' holistic wellbeing. Journal of Education and Special Education Technology, 4(1), 1-13. https://doi.org/10.18844/jeset.v4i1.4056

Agranovich, Y., Amirova, A., Ageyeva, L., Lebedeva, L., Aldibekova, S., \& Uaidullakyzy, E. (2019). The Formation of SelfOrganizational Skills of Student's Academic Activity on the Basis of 'Time Management Technology. International Journal of Emerging Technologies in Learning (iJET), 14(22), 95-110. https://online-journals.org/index.php/i-jet/article/ 
Ussenova, A. et al. (2020). Conceptual framework of the model of forming interethnic tolerance in the multicultural environment of the university, International Journal of Cognitive Research in Science, Engineering and Education (IJCRSEE), 8(2), 15-26

view/11755/6139

Ahi, B., \& Alisinanoglu, F. (2018). Effect of environmental education program integrated into preschool education on children's mental model development about "environment" concept. International Journal of Innovative Research in Education, 5(2), 29-40. https://doi.org/10.18844/ijire.v5i2.1247

Al-Bataineh, A., Brenwall, L., Stalter, K., \& York, J. (2019). Student growth through goal setting. International Journal of Learning and Teaching, 11(4), 147-161. https://doi.org/10.18844/ijlt.v11i4.4329

Anastasiadou, S. D. (2019). Personality traits in the light of the effectiveness of transformational vocational school leadership and leaders. New Trends and Issues Proceedings on Humanities and Social Sciences, 6(1), 184-191. https://doi. org/10.18844/prosoc.v6i1.4169

Bagila, S., Kok, A., Zhumabaeva, A., Suleimenova, Z., Riskulbekova, A., \& Uaidullakyzy, E. (2019). Teaching Primary School Pupils Through Audio-Visual Means. International Journal of Emerging Technologies in Learning (iJET), 14(22), 122140. https://doi.org/10.3991/ijet.v14i22.11760

Balyasnaya, L. K. (1995) Opisaniye v protsesse modelirovaniya vospitatel'nykh system. [Description in the process of modeling educational systems] In L. I. Novikovoy \& N. L. Selivanovoy (Ed.), Modelirovaniye vospitatel'nykh sistem: teoriyapraktika [Modeling educational systems: theory-practice] (243 p). Moskva: Izd-vo ROU. Retreived from: https://www. russianlawjournal.org/jour/article/view/987

Bespal'ko, V. P. \& Tatur, YU. G. (1989). Sistemno-metodicheskoye obespecheniye uchebno-vospitatel'nogo protsessa podgotovki spetsialistov [Systematic and methodological support of the educational process of training specialists] (144 p).

Cakmak, K., \& Uzunboylu, H. (2018). The roles of universities in the process of change. I/OAB Journal, 9(3), 109-120. https:// www.iioab.org/llOABJ_9.S3_109-120.pdf

Dafermos, M. (2016). Kriticheskiy analiz prinyatiya teorii L.S. Vygotskogo v mezhdunarodnom akademicheskom soobshchestve. [A critical analysis of the acceptance of the theory of L.S. Vygotsky in the international academic community.] Kul'turnoistoricheskaya psikhologiya, (3). Retrieved from: http://psyjournals.ru/files/83547/kip_3_2016_dafermos.pdf

Damy, A., \& Plascencia, M. G. L. (2020). Interdisciplinary block of learning challenges. Contemporary Educational Researches Journal, 10(1), 21-27. https://doi.org/10.18844/cerj.v10i1.4611

Öksüz, Y., \& Öztürk, M. (2017). The relationship between teachers' educational beliefs and their perceptions of multicultural competence. International Journal of Innovative Research in Education, 3(4), 210-220. https://doi.org/10.18844/ijire. v3i4.1861

Emrali, R. (2017). Today's artist identity as multicultural and hybrid identity. Global Journal of Arts Education, 6(4), 115-119. https://doi.org/10.18844/gjae.v6i4.1826

Elçi, E., \& Uzunboylu, H. (2020). The development of a universal and cultural values scale for values education. South African Journal of Education, 40, S1. https://doi.org/10.15700/saje.v40ns1a1850

Gay, G., \& Howard, T. C. (2000). Multicultural teacher education for the $21^{\text {st }}$ century. The teacher educator, 36(1), 1-16. https:// doi.org/10.1080/08878730009555246

Gershunsky, B. S. (2002). Philosophy of education for the 21st century. Training manual.

Gokalp, M. (2019). Investigation of social skill levels seen in high school students from different variables. Global Journal of Guidance and Counseling in Schools: Current Perspectives, 9(2), 56-66. https://doi.org/10.18844/gjgc.v9i2.4444

Kayedkhordeh, B., Mousavi, S., \& Abdi, M. (2018). Positive psychotherapy training on self-acceptance and positive relationships among female students. Global Journal of Psychology Research: New Trends and Issues, 8(4), 172-179. https://doi. org/10.18844/gjpr.v8i4.3941

Kececi, E., \& Kececi, G. (2016). Simmel's concept of culture. Global Journal of Sociology: Current Issues, 6(1), 24-30. https:/l doi.org/10.18844/gjs.v6i1.985

Konst, T., \& Kairisto-Mertanen, L. (2019). Developing innovation pedagogy. Contemporary Educational Researches Journal, 9(3), 74-84. https://doi.org/10.18844/cerj.v9i3.4224

Masat, S., Danaci, E., Sener, A., Erdogan, T. K., Cinarli, T., \& Koc, Z. (2018). The effect of emphatic tendemancy levels of nurses on their conflict resolution skills. New Trends and Issues Proceedings on Advances in Pure and Applied Sciences, (10), 11-25. https://doi.org/10.18844/gjpaas.v0i10.3740

Mazur, I. I. (2014). Upravleniye proyektami: ucheb. [Project management: textbook] Posobiye (959 p). In I. I. Mazura, V. D. Shapiro (Eds.). Omega-L.: il.s

Metin, S., \& Aral, N. (2020). The drawing development characteristics of gifted and children of normal development. Cypriot Journal of Educational Sciences, 15(1), 73-84. https://doi.org/10.18844/cjes.v15i1.4498

Metin, S., \& Aral, N. (2020). The drawing development characteristics of gifted and children of normal development. Cypriot Journal of Educational Sciences, 15(1), 73-84. https://doi.org/10.18844/cjes.v15i1.4498

Miyamoto, Y., Yoo, J., Levine, C. S., Park, J., Boylan, J. M., Sims, T., ... \& Coe, C. L. (2018). Culture and social hierarchy: Selfand other-oriented correlates of socioeconomic status across cultures. Journal of Personality and Social Psychology, 115(3), 427. https://doi.org/10.1037/pspi0000133

Mynbayeva, A. K. \& Anarbek, N. (2015). Printsipy proyektirovaniya akademicheskikh strategiy vuzov kak instrumentov obrazovatel'noy politiki. Vestnik KazNU. Seriya «Pedagogicheskiye nauki», 1(44), 115. Retrieved from: https://bulletinpedagogic-sc.kaznu.kz/index.php/1-ped/article/view/287

Nazarbayev, N. A. (1996). Na poroge XXI veka [On the threshold of the XXI century]. Almaty, O'ner.

Ozkisi, H., \& Topaloglu, M. (2018). Application for sentiment and demographic analysis processes on social media. Global Journal of Computer Sciences: Theory and Research, 8(3), 143-148. https://doi.org/10.18844/gjcs.v8i3.4026

Pidkasistyy, P. I., Fridman, L. M., \& Garunov, M. G. (1999). Psikhologo-didakticheskiy spravochnik prepodavatelya vysshey shkoly [Psychological and didactic reference book of a teacher of higher education]. Moscow, Pedagogicheskoe obshchestvo Rossii Publ.

Plotnikova, N., \& Strukov, E. N. (2019). Integration of teamwork and critical thinking skills in the process of teaching students. Cypriot Journal of Educational Sciences, 14(1), 1-10. https://doi.org/10.18844/cjes.v14i1.4031

Pinpathomrat, N. (2017). Cultural Model of Information Technology Usage (CMITU). Global Journal of Information Technology: Emerging Technologies, 7(2), 42-49. https://doi.org/10.18844/gjit.v7i2.2227 
Raluca Simion, M. (2016). Fractal Images - A New Way to Reduce Stress and To Improve Educational Workspaces. Global Journal of Psychology Research: New Trends and Issues, 6(1), 20-30. https://doi.org/10.18844/gjpr.v6i1.477

Rubinstein, A. (2003). "Economics and psychology"? The case of hyperbolic discounting. International Economic Review, 44(4), 1207-1216. Retrieved from: https://citeseerx.ist.psu.edu/viewdoc/summary?doi=10.1.1.452.3042

Sağıroğlu, N., \& Uzunboylu, H. (2018). Analysis of the published articles related to autism in Turkey: A model proposal for students. Journal of Education and Special Education Technology, 4(1), 14-23. https://doi.org/10.18844/jeset.v4i1.4105

Sartayeva, N. T., Kenesbaev, S. M., Zhailauova, M. K., Nurzhanova, S. A., Uaidullakyzy, E. (2018). Possibilities of the subject 'information and communication technologies' in accustoming primary school students to research activities. International Journal of Interactive Mobile Technologies, 12(6), 35-46. https://doi.org/10.3991/ijim.v12i6.9622

Simion, M. R. (2016). Fractal Images-A New Way to Reduce Stress and To Improve Educational Workspaces. Global Journal of Psychology Research: New Trends and Issues, 6(1), 20-30. https://doi.org/10.18844/gjpr.v6i1.477

Sorakin-Balli, Y., Basari, S., \& Guldal-Kan, S. (2020). The relation between classroom management skills and empathic tendencies of high school teachers high school teachers' classroom management skills and empathic tendencies. Cypriot Journal of Educational Sciences, 15(1), 144-152. https://doi.org/10.18844/cjes.v15i1.4595

Stefanenko, T. S. (2008). Etnopsikhologiya: Uchebnik dlya vuzov [Ethnopsychology: Textbook for universities] $\left(4^{\text {th }}\right.$ ed., 368 p). Moscow, Russia: Aspekt Press.

Tenbele, N. T. (2019). Effectiveness of internal control system in higher learning institution, in Nairobi, Kenya. Global Journal of Business, Economics and Management: Current Issues, 9(3), 143-155. https://doi.org/10.18844/gjbem.v9i3.4399

Triandis, H. C. (1994). Culture and social behavior. New York: McGraw-Hill Inc. https://www.scirp.org/ (S(351jmbntvnsjt1aadkposzje))/reference/ReferencesPapers.aspx?ReferencelD=375050

Turalbayeva, A. T., Sultanbek, M., Utyupova, C. E., Aidarov, B. Z. \& Uaidullakyzy, E. (2017). The general preparation of the training of elementary school and the family and the education of gifted children school in cooperation principles: Ponte 73(4), 239-251. https://10.21506/j.ponte.2017.4.54

Usmani, M., \& Khatoon, S. (2018). Impact of programme evaluation through self-assessment in higher education institutions in Pakistan. Contemporary Educational Researches Journal, 8(4), 134-141. https://doi.org/10.18844/cerj.v8i3.3638

Uzunboylu, H., \& Altay, O. (2019). State of affairs in multicultural education research: a content analysis. Compare: A Journal of Comparative and International Education, 1-20. https://doi.org/10.1080/03057925.2019.1622408

Vasiliene-Vasiliauskiene, V., Vasilis Vasiliauskas, A., Meidute-Kavaliauskiene, I., \& Sabaityte, J. (2020). Peculiarities of educational challenges implementing project-based learning. World Journal on Educational Technology: Current Issues, 12(2), 136-149. https://doi.org/10.18844/wjet.v12i2.4816

Winch, J. (2020). An investigation of students' preferences in Japanese teaching and learning. Global Journal of Foreign Language Teaching, 10(1), 72-84. https://doi.org/10.18844/gjflt.v10i1.4571

Zhumabayeva, Z., Uaisova, G., Zhumabayeva, A., Uaidullakyzy, E., Karimova, R., \& Hamza, G. (2019). Issues of Kazakh language teaching in elementary classes in terms of the meta-subject approach. Cypriot Journal of Educational Sciences, 14(1), 158-170. https://doi.org/10.18844/cjes.v14i1.4123

Zorluoglu, S., Kizilaslan, A., \& Donmez Yapucuoglu, M. (2020). The analysis of 9th grade chemistry curriculum and textbook according to revised Bloom's taxonomy. Cypriot Journal of Educational Sciences, 15(1), 9-20. https://doi.org/10.18844/ cjes.v15i1.3516 